\title{
Politics, Identity and Temporality in Colonial Algeria in the Early Twentieth Century
}

\begin{abstract}
In the first quarter of the twentieth century, colonial Algeria was marked by profound social, cultural and political tensions that were compounded by a concatenation of events triggered by the First World War. Within a context marked by the determination of settlers and the colonial administration to maintain the colonial status quo, a small group of French-educated Algerian political activists known as the Jeunes Algériens (Young Algerians) emerged onto the political scene and called for reform and for more rights for the colonised. This study examines aspects of political discourse in the colony during that period and considers how notions of temporality were invoked on both sides of the colonial divide and shaped political debate at the time. It discusses some of the ways in which history and memory as well as conceptions of Algeria's future were conjured up, on the one hand, by French politicians, settlers and writers in ways that sustained France's hegemonic colonial discourse, and on the other, by the Jeunes Algériens in order to emphasise the inequity of the colonial order, seek acceptance within the French nation and foreground specific political claims and demands.
\end{abstract}

Keywords: Algeria; Young Algerians; Colonialism; History; Memory; Emir Khaled 
As James H. Liu and Dennis J. Hilton remind us, the role of the past, in its historical and memorial dimensions, is to provide us with 'narratives of who we are, where we came from and where we should be going' $(2005,537)$. Yet, the relationship between history and memory that shapes the past is a contentious one, and has been the subject of notable scholarly debate over the few decades. Studies such as Maurice Halbwachs' La mémoire collective (1968) and Pierre Nora's Les lieux de mémoire (1989), for example, have conceived of the past by foregrounding what they see as a dichotomy between history and memory. ${ }^{1}$ More recently, however, some historians and philosophers have questioned such views and developed alternative interpretations of that relationship. ${ }^{2}$ As François Dosse points out: 'The false dilemma of a choice to be made between a history founded on a pact of truth [contrat de vérité] on the one hand, and a memory nurtured by a sense of loyalty on the other, is now being transformed through a real historiographical shift' $(1998,8)$. Of course, history may not be conflated into memory and conceived simply as 'an Art of Memory', to use Patrick Hutton's term (1993). Rather, the relationship between history and memory should be perceived as one of complementarity: 'the first movement [history] which foregrounds critical enquiry and distanciation', Dosse argues, 'is followed by a second stage [memory] that complements it and without which history would just be a kind of exoticism: it is a recollection of meaning that aims to appropriate the diverse sedimentations of meaning passed on by previous generations, of unrecognised possibilities that litter the past of the vanquished and the silenced of history' $(1998,8)$. Reflecting on Algeria's colonial history, Enzo Traverso also emphasises the connectedness of history and memory when he points out that "history and memory interact [...] like "fluctuating categories within a dynamic field"” $(2005,36)^{3}$

The complementarity between history and memory that shapes the past should also be elucidated in relation to present circumstance. As philosopher Alphonse Dupront points out, 
there is 'no existence of the present without the presence of the past' (as quoted in Dosse $2003,145)$. It is this tension between history and memory that informs the past, and the relationship between past and present that this article seeks to explore through a study of French and Algerian cultural and political discourse in the aftermath of the First World War. ${ }^{4}$ This study considers some of the ways in which history and memory were invoked, on the one hand, by French writers, civil servants, politicians and settlers as part of a hegemonic discourse, and on the other, by the Jeunes Algériens (Young Algerians), the small group of French-educated political activists who, during the first quarter of the twentieth century, called for reform of the colonial order, more rights for Algerian Muslims, and fairer representation in elected assemblies. It examines some of the tensions that marked specific representations of history and memory, and the ways in which they were informed by their particular circumstances within the colonial context from which they emerged. It is argued that the post-World War I period, particularly between 1919 and 1923, was characterised by political tensions and increased political activism among Algerians who sought colonial reform, leading to a gradual shift in the way the past was construed in their discourse. The final part of this article will seek to go beyond the binary relationship between the past and the present to determine ways in which specific conceptions of temporality could be articulated by both the French and the Jeunes Algériens to imagine Algeria's future destiny. As James Brow points out: 'Socially organized knowledge of the past both reflects and affects the distribution and exercise of power [...] contending versions of the past figure prominently in what it is useful to describe [...] as the struggle of hegemony' $(1990,3) .^{5}$ During that period, while the past played a part in the ideological construction of French hegemony, it also constituted a notable feature of the counter-hegemonic discourse of the colonised Algerians. 


\section{The Jeunes Algeriens and their press}

At the turn of the twentieth century, the educational divide between European settlers and 'Muslim subjects' remained stark. While 84 percent of European and Jewish children went to primary school, only 25,284 Muslim pupils out of a total school age population of 676,000 (3.6 percent) had access to education in colonial Algeria in 1900, and fewer still were able to continue their schooling beyond the primary stage (Mourey and Brunel 1902, 28-30). Among this minority were a small number of French-educated Algerians whom the French called 'évolués'. As Jean Mirante, Directeur des Affaires indigènes (Director of Native Affairs) at the Gouvernement général of Algeria, declared in 1926: 'the number of indigènes [natives] in this category is not significant yet. Next to the dozens or, at best, the few hundred of indigènes évolués, there is the large mass of no less than five million Muslims'

(Gouvernement général de l'Algérie 1926, 554). Yet, this small group of educated Algerians was to have a lasting impact on colonial politics in Algeria. From the 1880s onwards, they started to coalesce around educational and sports associations and to develop forms of political engagement. This period marked the emergence, for the first time since the invasion of Algeria in 1830, of a distinct Algerian political voice in the colony, one that demanded urgent reforms of the colonial order and the granting of rights to the colonised. The political views of militants ranged from those who, like Dr Belkacem Bentami, an ophthalmologist from Algiers, sought complete assimilation in the French nation to those militants who like M'hamed Ben Rahal, ${ }^{6}$ a notable from Nedroma, defended a distinct Algerian identity based on religious belonging and the Arabic language. From the early twentieth century onward, those activists gradually adopted the name 'Jeune Algérien' previously used by some French politicians and observers to describe them in order to situate their action in continuity with emerging political movements across the Muslim World (the Young Turk revolution of 1908, 
and the development of the Young Egyptian and Young Tunisian movements) and through a referential framework familiar to the coloniser (Fromage 2012, 238-39).

On the eve of the First World War, the two main Jeune Algérien currents came together under the leadership of Emir Khaled who, as Emir Abd el Kader's grandson and as a captain in the French army, appealed to both militants favouring assimilation into the French nation and traditionalists seeking to nurture Algerian's distinct cultural and religious heritage (Ibid., 240). Following the adoption of the law of 4 February 1919, known as the Jonnart Law, extending voting rights to local councils and regional assemblies to a small proportion of the Muslim population, the Jeunes Algériens experienced significant electoral successes in Algerian elections between 1919 and 1923, despite the opposition of European settlers and obstruction from the administration and pro-colonial Muslim notables. Their political programme included a number of demands aimed at reforming the status and rights of Algerians: extension of political rights, Parliamentary representation, access to French citizenship for Algerians without the requirement for them to formally abandon, or in the eyes of many Algerians, renege on their Muslim status, abolition of the discriminatory 'Code de l'Indigénat' (Native Code) imposed on Muslims, reform of the appointment of Muslim judges and administration, development of education (promotion of the Arabic language), agrarian reform and investment in agriculture (L'Ikdam, November 17, 1919). ${ }^{7}$

Despite the moderation of their political programme and activism, the French colonial administration saw Khaled and the Jeunes Algériens as protonationalists. As a police report assessing Khaled's political legacy stated in 1923:

From 1919 to the last few months, the 'jeunes algériens' or Khaledistes [...] constituted a movement in which one could see the first awakening of Algerian nationalism [...] Thus, Mr Khaled was, for some - particularly the intellectuals - the 
spokesman for their political demands [...]; and for others, a historical symbol that they respected passively rather than actively because of his ancestry and the apparent fervour of his religious faith. For those two reasons, he represented a real danger [...] and, during elections, he became a party leader who was almost always guaranteed an overwhelming majority ('Rapport sur la situation politique et administrative des indigènes de l'Algérie au $1^{\mathrm{er}}$ mai 1923', 1923).

In 1914, Emir Khaled asserted his political views and evoked his grandfather's legacy. His place, he stated, was among 'this elite that fights, against all odds, for the good of France by improving the lives of fellow Muslims' and he reminded his critics among the French of his 'brilliant conduct' in the Moroccan campaign and the 'noble behaviour of my grandfather, the great Abdelkader, who after a loyal fight against France, became her indefectible friend' (L'Ikdam, March 5, 1919). This claim to political legitimacy was reinforced by his actions on the battlefield in France during the First World War that won him the Légion d'honneur. Importantly, Khaled's trajectory shows that his political views were often more assertive than those of many Jeunes Algériens at the time. Importantly, Khaled's trajectory shows that his political views were often more assertive than those of many Jeunes Algériens at the time. In his speeches and his writing, he emphasised the need to develop education in Arabic, consistently refused to accept French citizenship, and often referred to the specificity of Algerian cultural and religious identity. He also evoked his grandfather's resistance against French colonisation as the 'Algerian War' and as an act of 'defence for his fatherland' (L'Ikdam, March 24, 1922). In the aftermath of the War, he was also influenced by US President Woodrow Wilson's rhetoric of self-determination and by other significant developments taking place internationally. ${ }^{8}$

During that period, and until his eventual exile to the Middle East in the mid-1920s, his political engagement in the Jeunes Algériens movement was to have a profound influence 
on the emergence of Algerians on the political scene. The years directly preceding the start of the First World War constituted the background for the formation of the Jeune Algérien political programme. While they broadly supported the introduction of conscription for Algerians in 1912, they also took this opportunity to demand modest reforms and compensations for Algerians. ${ }^{9}$ As Urbain Sénac - a retired parliamentarian of the Left stated in the same year: 'What do Arabs of Algeria ask from us as a compensation? Very little: more justice, fewer emergency legislation, the maintenance of their religious beliefs and electoral rights' (L'Islam, February 11, 1912). As the French government instituted conscription for Algerians with the decree of 3 February 1912, journalist Victor Barrucand, ${ }^{10}$ editor of the 'indigénophile' newspaper L'Akhbar wrote: 'A “Jeune Algérien” party was born and has just received the baptism of blood. This party is necessary [...] the attitude of Europeans who have turned their back on the French ideal explains the increasing assertiveness of progressive indigènes who were educated in our schools and are willing to take our principles seriously' (L'Akhbar, February 5, 1912, as quoted in L'Islam, February $25,1912)$

Algerian activists were faced with significant difficulties in their efforts to publish newspapers and present their views in publications. Despite its loyalist and assimilationist stance, the launch of El Hack (the truth) in the summer of 1893 caused such serious concern among settlers and the administration that it was banned by the colonial authorities in its second year (1894) after only twenty one issues had been published. But other newspapers followed: El Misbah (the light) was created in Oran in 1904; L'Islam in Bône in 1909 and Le Rachidi (the guide) in Djijelli in 1911. At the time, the Paris based La Revue Indigène noted the increasingly important role played by 'indigènes' in shaping what they described as a 'community of sentiment' and political action among North Africans: 'The natives [...] have realised that their fortunes are dependent on solidarity with each other. This is already 
noticeable in the French language native press, whose creation is the most characteristic development of the last few years. The editors of the five or six weekly newspapers published in Tunisia and Algeria know each other; they correspond and confer with each other, and organise joint campaigns' ('Comment organiser l'Afrique du Nord! Articles du Temps et de la Revue Indigène’ 1912, 3).

Importantly, those publications consistently paid homage to a France described as 'the cradle of human liberties' (L'Islam, January 7, 1912), and appealed to its universalist traditions to call on the French people to grant rights to Muslims and give them wider access to education: 'Dear brothers of France $[\ldots]$ we are speaking in the name of millions of miserable people who are dying under the heavy yoke of misery they endure [...] Help us, give us our old dignity and happiness back [... Educate us and make us your equals since your motto is: Liberty, Equality, Fraternity' (El Hack, January 14, 1894). ${ }^{11}$ In the aftermath of the First World War, the launch of the newspaper L'Ikdam (boldness) in Algiers under the patronage of Emir Khaled marked a new phase in the political engagement of the Jeunes Algériens and its evolution into an influential social movement. ${ }^{12}$ Suspected by the colonial administration of nationalist tendencies, the newspaper sought to emphasise their loyalty towards France but nevertheless stated that 'fellow Muslims no longer are the amorphous mass of old' in Algeria (L'Ikdam, March 22, 1919; 'Rapport mensuel sur la situation politique et administrative des indigènes de l'Algérie au $1^{\mathrm{er}}$ mai 1923', 1923). Their newspaper aimed to be 'the protector of the weak, the clarion call for just demands, the artisan of the rule of equality and fraternity'. It was created, they claimed, at a time that sounded the death knell for 'the unjust and barbaric imperialism' and the 'regime of Arabophobia'. They drew inspiration from Wilsonian principles to call for the establishment of a 'new France' in Algeria (L'Ikdam, January 15, 1919). ${ }^{13}$ This was a new dawn, in the 
eyes of the Jeunes Algériens, one in which conceptions of temporality fed into the protonationalist turn observable during that period in the colony.

\section{Evocations of the France's revolutionary past in the aftermath of the First World War}

As John May and Nigel Thrift have argued, a radical restructuring in the nature and experience of time and space occurred from the middle of the nineteenth century to the eve of the First World War $(2003,7)$. This process which affected Algeria in particular ways during that period due to the social, cultural and political upheaval brought about by colonisation, became even more salient following the concatenation of dramatic events brought about by the First World War. This War had had a profound impact on colonial relationships and on the politics of colonial Algeria. On the international scene, it revealed significant rifts and led to momentous change from a political, economic, cultural point of view (Glipin 1981, 1). As Gilbert Meynier points out, the upheaval of the War 'pose[d] the colonial question in new terms' $(2015,385)$. The rapid social, political and cultural changes and instability caused by the War informed shifts in colonial relationships on a number of levels. It triggered the mass displacement of Algerian men: some 300,000 Algerian men came to France during that period: more than 172,000 men served in the army and between 109,000 and 119,000 worked in the métropole between 1914 and 1918 (Ibid., 405). ${ }^{14}$ Despite the discrimination that they endured in France, their experience living in the ranks of the army or working in factories outside what Benjamin Stora called the 'colonial ghetto' $(1996,14)$ - had a significant impact on them as well and caused concern among settlers and the colonial administration. Upon their return, many demobilized Algerians experienced great difficulties readapting to a colonial society affected by economic difficulties, a society that had, in their eyes, barely evolved or developed since they had left. 
The Jeunes Algériens seized upon the political climate of the post-war period to advance their political aims. From 1919 onwards, the role played by Algerians in the First World War became a central theme in their discourse, enabling them to further develop particular notions of nationhood and belonging, as well as claims to political legitimacy. In many respects, those arguments countered the views expressed by the settler press according to which Algerians did not have the attributes to become French citizens. Equally, the socalled 'indigénophile' French writers, journalists and politicians who belonged to the Comité d'Action Franco-Musulman (Franco-Muslim Action Committee) and who supported reform in Algeria, considered that the war had been more beneficial to their cause more than 'twenty years of propaganda' ${ }^{15}$ It had given Muslim soldiers and colonial workers the opportunity during the war to 'prove their loyalty towards France' (L'Ikdam, March 15, 1919).

Therefore, the war and its legacy became a contested ideological terrain where conflicting interpretations of colonial relationships, nationhood and temporality clashed, and where identities were re-asserted, challenged or re-defined. The context of the post-war years fostered a political environment in which history and memory acquired renewed agency both for the French and the Algerians. As Paul Deschanel, President of the Parliament, declared on 11 November 1918, the nation that had emerged victorious was 'the France of all times, our old France like the France of the Revolution et of the triumphant Republic [...] that respects your traditions, your customs, your freedoms, your beliefs' (as quoted in Lomont 1924, 176177). This war had been waged 'for the defence of peoples' freedom, for civilisation and for humanity against Germanic barbarism and despotism', historian Marius Vachon claimed (1916, vii). Inevitably, such evocations of the Revolutionary past and Republican ideals underpinning France's fight during the War had a profound impact on the Jeunes Algériens. As they stated in L'Ikdam in 1919: 'Now that the cannons have stopped firing and that the threat has gone, it is time to remember' (L'Ikdam, March 17, 1919). The past was summoned 
not only to justify and celebrate Algerians' contribution to the war effort but also to underscore their struggle for equality and rights in the aftermath of the War. Indeed, memories of the War and France's revolutionary past (including the night of 4 August 1789 when the French Constituent Assembly abolished feudal privileges) were invoked by them to denounce the perpetuation of the colonial status quo in Algeria: 'The War is going on... it is an internal war $[\ldots]$ We believed [...] that sheltered by the union sacrée, we would have our own night of 4 August in Algeria! [...] The flame of the revolutionaries of 1789 did not cross the vast expanse of water that separates us from the other continent [...] We believed that the brotherhood of arms, cemented with our most precious blood, would continue after this terrible turmoil! Chimera! Empty words! The hunt for the Jerries has barely finished yet they are re-starting the war against the fellahs [peasants]' (L'Ikdam, April 5, 1919).

\section{The longue histoire and colonial politics}

Evocations of Algeria's long history (longue histoire) became more salient in the discourse of the Jeunes Algériens movement in the years that followed the First World War. This was particularly noticeable between 1919 and 1923 when their political views gradually shifted to expound a more critical assessment of colonial rule and express their frustration at the lack of reform in Algeria. Political activists' reference to history constituted a form of counterdiscourse that was very much a reaction to the narratives on the past that pervaded colonial discourse on Algeria. Indeed, in the early twentieth century French journalists, politicians, writers and observers evoked Algeria's Roman past to articulate, justify and expound France's 'civilising mission' and colonial oeuvre, and to downplay the cultural influences deriving from subsequent dominations, particularly Arab civilisation, on Algeria. This echoed the French fascination with Algeria's ancient, Latin past. As as Patricia Lorcin has shown, this Latin past achieved the status of a foundation myth - particularly in the second half of the nineteenth century - both in terms of framing Western colonial presence within 
the longue histoire and foregrounding the Berber myth (2002, 295-329). In 1901, historian and Académie Française member Gaston Boissier (1912) highlighted the importance of understanding Africa's Roman past in order to further France's colonial project. He saw the past as 'la garantie du présent' (a guarantee for the present) and as key to France's consideration of what North Africa 'will become':

In order to know what the future holds for our African possessions $[\ldots]$ is it enough to enquire about the present? I don't think so. It seems to me that the past deserves to be heard. We are not the first people who have come from northern lands to settle in Africa; we have had some illustrious predecessors who have set foot on this land, as we have done, and who have governed it gloriously for more than five centuries [...] we cannot ignore the lessons and examples that the past can give us [...] they can teach us a lot if we know how to question them (Boissier 1912, i-ii).

Conceptions of Algeria's destiny informed by the past inflected political considerations and the deliberations of Algerian assemblies at the beginning of the twentieth century. For example, Charles-Albert Joly, Rapporteur Général du Budget (Budget Rapporteur) for Algeria, concluded his declaration on the colony's budget in June 1913 by painting an orientalist portrait of Algerians as violent, indolent and devoid of civilisation and history and making reference to Roman North Africa. He argued that North Africa, left on its own, had in the past been afflicted by decline, and that it had only shone when it had found itself under the European domination: 'left to its own devices [...] gradually under the influence of its climate, it fell asleep, and its main preoccupation was to live without making any effort [...] The life of the African is a combination of violent passions and prolonged indolence' (Gouvernement général de l'Algérie, Délégations Financières 1918, 644). French colonisation, he claimed, could create a 'movement comparable to that of the Roman conquest': 
The citizenship granted by Rome to Africans provided her with soldiers who, later, gave her emperors; and when the powerful Latin organisation collapsed under the blows of barbarians, settlers in Africa had no option but leave this land that their fathers had made fertile; they were driven out by the resurgent anarchy under the ruins of empire and by the long-repressed natural forces of the climate and the native race (644).

At the turn of the twentieth century, a number of writers like Louis Bertrand and Robert Randau produced novels and essays that echoed and reinforced such conceptions. ${ }^{16}$ Writer Césaire-Antoine Fabre drew on particularly blurred notions of history to describe the Arab 'conquest' of North Africa from the seventh century CE onwards, as nothing more than a destructive force: 'The first Arab invasion occurred like a torrent. Everything disappeared. The most powerful civilisation that the world had ever known sank into oblivion. Soon, we forgot where Hippo and Utica had once stood. Carthage, in turn, disappeared, but even if more than a thousand years had passed on this African land, Europe did not forget Hannibal, Jugurtha, Sophonisba, Augustine and Belisarius' (Fabre 1901, 24). France's colonisation of Algeria, therefore, was celebrated by Fabre as a symbol of the return of Latin civilisation into North Africa and as the true home of North Africa's historical memory: 'All praise to our France that, remembering that she is the most perfect and best living creation of Latin civilisation, has re-established the bond interrupted by ten centuries of Barbarism and brought back to life civilisation, well-being, peace, the cult of science and the Arts in the land of the Severus, Apuleius and Augustine (24-25). Here, France's colonisation of Algeria was presented as a return of civilisation, as the last stage of a historical process that had reestablished North Africa's 'true', Latin identity.

In L'Echo d'Alger, the main Algerian daily newspaper at the time, prominent settler Fernand Ancey argued that France's destiny was to remain in Algeria and last even longer than preceding civilisations (L'Echo d'Alger, March 2, 1919). ${ }^{17}$ His conception of history, 
which echoed that of many pro-colonial writers at the time, was framed in ways that justified the colonial status quo. For him, the civilisational divide between the French and their subjects constituted a reason for the continued marginalisation of Algerians: 'If one considers that it took us twenty centuries to shape our civilisation $[\ldots]$ how can we accept that our natives, whose customs take us back to the origins of our own civilisation, could from one day to the next, become our equals thanks to the ballot paper and without having shown any capacity to become civilised?' (L'Echo d'Alger, March 16, 1919). Ancey described Algerian Muslims as '[a]1l those natives who only know of life its animal functions, of politics obedience and servility'. He warned that under the influence of the few educated and 'ambitious' ones among them, they would pose a danger for the colony and soon become the masters of a land of which they were, until then, mere subjects (L'Echo d'Alger, February 16, 1919). Ancey's article betrayed the ‘siege mentality' of many settlers and their fear of miscegenation. It summoned a particularly narrow conception of Algeria's history to paint a portrait of an Algerian population whose atavistic traits rendered them incapable of évolution and progress and justified France's continued domination, and to oppose the modest reforms brought about by the Law of 4 February 1919:

Already overwhelmed by foreigners [and by] natives, the French will gradually be excluded from this Algerian race that is taking shape and that will, in turn, disappear. They will either be absorbed by the primitive [native] race or driven out. This is how the Romans withdrew because they could not assimilate natives and did not want to be assimilated themselves, they had no option but leave. They were defeated by a people that remained implacable for centuries - a period during which no civilisation has left a mark - a people whose customs, clothing or even work tools have never changed (L'Echo d'Alger, February 16, 1919).

Like many other scathing attacks on Muslims published in the settler press, ${ }^{18}$ this article prompted a response from L'Ikdam. In this article, the Jeunes Algériens drew on three main 
references - France's Revolutionary past, sacrifice and history - to challenge Fernand Ancey's conception of the colonised. They criticised him for calling on France to deny Algerians the benefits of a 'Declaration of the Rights of Man that has gone around the world' and to maintain them in a state of serfdom: 'We [are] the last serfs of humanity [...] we, Arabs, a race treated as the lowest of the low, are doomed to servitude' (L'Ikdam, March 29, 1919). They evoked the sacrifice made by Algerian soldiers in the First World War to underscore their claim for rights: 'this law of justice that we have been waiting for impatiently [...] haven't we earned it by shedding all the blood of our kin on the land of France and Belgium?' Algeria's 'long history' was also a terrain on which the colonial project was disputed and contested by the Jeunes Algériens. They drew on the past greatness of Arab civilisation to counter Fernand Ancey's account of Algeria's history and argued that the Romans had long disappeared when the Arabs conquered Algeria in the seventh century:

Truth is Mr Ancey's least worry; the Romans left - he needs them, so he calls them! Since Mr Ancey searches history for imaginary weapons to use against us, he should re-read it, or rather, read it. He will see that this indomitable and barbaric people had its hour of splendour; he will learn that this race which he calls inferior, has produced great poets, philosophers, scholars and physicians. Whereas in fact the Romans that he opposes to us no longer produce any. If he has any spare time, he should travel to Spain; after having contemplated the Alhambra of Granada, the Mosque of Cordoba, the Alcazar of Seville, maybe he will concede that our ancestors have experienced other aspects of life than just its animal functions! (L'Ikdam, March 29, 1919)

As this passage shows, history was summoned by the Jeunes Algériens as a means to counter a colonial discourse that dehumanised and marginalised the colonised. It is worth noting, however, that their historical references focused primarily on what they saw as the greatness of the past Arab civilisation. They rarely evoked the contributions made by North Africans to 
politics, culture, the arts and religion in the pre-Islamic, pre-Arabic past. Figures like Augustine, bishop of Hippo, philosopher Lucius Apuleius, Jugurtha, King of Numidia, the Severan dynasty tended to be discussed by pro-colonial French writers and politicians rather than by the Jeunes Algériens. Through evocations of the greatness of their own Islamic past, they challenged the coloniser's historical narrative and memorial representations marked by closure and opposed the settlers' use of particular interpretations of history as a justification for the maintenance of discriminatory measures against them. Their interpretation of history was, clearly, equally selective as they tended to marginalise North Africa's Berber history prior to the Arab conquest. However, their discourse underpinned demands for equality, rights and reforms in the colony. It was informed by a particular conception of temporality that empowered Algerians and highlighted Muslims' connections with, and contribution to European civilisation.

Indeed, Arab civilisation was not represented as a high culture that evolved in isolation. It was described as a precursor to Western civilisation: 'For centuries', they declared, 'Arabs held the perfect and ever more radiant torch of civilisation in their hands... They then placed this torch in other hands, and today those hands are still holding it and raising its shining light ever higher' (L'Ikdam, February 2, 1923). In the Jeune Algerien newspaper, Fehmy al Moudariss, a teacher of Arabic literature, also argued that Arab civilisation had had a major influence on European civilisation from a scientific and intellectual point of view. His description of the past aimed to counter colonial narratives and was no less problematic than that of the French. Arab civilisation, he claimed, was a 'great culture to which modern Europe is indebted'. The Arab people had, in the past, shown 'their great tolerance, their liberal spirit, their organisational abilities '. By contrast, he wrote, Europe, '[a]fter more than a thousand years of terrible warfare, of ancient hatred and merciless carnage [...] was never able to reach a similar level of tolerance' (L'Ikdam, 
February 2, 1923). To some extent, his article reflected the narrow constraints within which conceptions of history were used to underpin claims of national belonging and demands for rights at the time. The historical references used here were, of course, redolent of French discourse. When al Moudariss stated that the Arab civilisation had, in its time, also been a 'powerful factor of modern regeneration', he drew, to some extent, on notions also invoked by colonists. Indeed, settlers during that period often presented colonisation as a process of regeneration, ${ }^{19}$ and emphasised the need to undertake this 'work of regeneration [oeuvre de régénération'] of Algerian races' (Bernard 1912, 5). Quoting philosopher and historian Ernest Renan and conveying some of the prejudiced views on the Turks and the Berbers expressed by settlers, al Moudariss claimed that the decline of Arab civilisation started in the thirteenth century when their power was lost to the Turks and the Berbers whom he described as 'coarse, brutal races devoid of esprit'. He echoed but also disrupted French narratives of Western imperial expansion and of the civilising process when he presented Arabs as the worthy heirs of the ancient Greeks and past Arab conquests as instrumental to the spreading of an Arab civilisation whose reach had been universal:

The Greeks' claim to the gratitude of humankind, the Arabs also have a claim to it; the civilised peoples have a duty not to ignore a people which $[\ldots]-$ during the darkest moments of History when ignorance had thrown the world into barbarism and almost buried ancient civilisation for ever - have saved civilisation and expanded it through new conquests, and spread it in all the places its armies have reached (L'Ikdam, February 2, 1923).

Interestingly in this article, the author failed to denounce the idea of empire. Rather, he adopted conceptions of colonial grandeur but displaced the French colonial narrative by reasserting Arab culture as an intrinsic part of human civilisation, as the missing link in the civilizational chain from ancient to modern times. Yet, at the same time, and by contrast to that of some settlers supporting the colonial status quo, his conception of history was not an 
entirely closed one. Indeed, he emphasised the role that European civilisation could play in reviving and guiding the Orient towards modernity and fraternity. In the same issue of L'Ikdam, an article signed by Naoum made similar historical claims to highlight affinities between Arab civilisation and revolutionary France: 'Doesn't this prolific people resemble the people of the great Revolution? I tell you, they are two brotherly peoples'. However, Naoum warned that this sense of kinship would eventually be replaced by hatred and strife unless reforms were introduced in Algeria by the French: 'This would mark the end of any influence they once had. The Arabs are a proud and indomitable race and they would not hesitate to burn what they once adored. This would herald the reign of hatred, of fratricidal hatred' (L'Ikdam, February 2, 1923).

\section{Memory, conflict and belonging}

Memories of conflicts and events that had taken place on both sides of the Mediterranean since the end of the nineteenth century were used, in different ways, by settlers and the Jeunes Algériens to reinforce specific political views on the colonial relationship. The Franco-Prussian War of 1870 and the Kabyle insurrection led by Mokrani in 1871 are cases in point. For example, Fernand Ancey, in L'Echo d'Alger, made reference to the Kabyle insurrection of 1871 and the local revolt of Margueritte of 1901 as reflections of the threat that Algerians posed, in his view, to France's colonial domination (L'Echo d'Alger, February $16,1919) .{ }^{20}$ In his article, memories were framed in ways that reinforced divisions between ethnic groups in Algeria. Dismissing the Jeunes Algériens' declarations of loyalty to the French nation, he compared Algerians under French colonial rule with the Alsatians under German occupation:

One should not ignore the fact that $[\ldots]$ the natives do not like us, just like we should not pretend that our people of Alsace and Lorraine like the Germans and that they have yielded to 
their yoke through devotion and gratitude. Our ability to maintain our rule in Algeria will disappear when their national feelings have awoken. We are powerless in the face of such peril' (L'Echo d'Alger, March 16, 1919).

Interestingly, in this article, Ancey does not invoke France's rhetoric on its assimilationist and civilising role in Algeria; instead, he equates French rule in Algeria with what most French people considered at the time as the unjust and brutal occupation of an integral part of French territory (Alsace) by a foreign force.

By contrast, the Jeunes Algériens often sought to 'reach out' to France. They invoked the Republican notion of 'don du sang' (blood tax) as well as memories of the sacrifice made by Muslim soldiers during the Franco-Prussian war of 1870-1871 and other French conflicts to seek acceptance and reconciliation within the French nation. In a telegram addressed to General Adolphe Messimy ${ }^{21}$ in April 1919, for example, leading Jeunes Algériens Emir Khaled, Mohamed Soualah, Omar Bouderba, Ben Ali Mouhoub and Mustapha Tamzali expressed their satisfaction to see 'the ashes of the Turcos [North African soldiers] fallen in 1870 ' return to France and reasserted their 'profound attachment, our faithful loyalism' towards France (L'Ikdam, April 5, 1919). ${ }^{22}$ They called for reform in Algeria, a land that they described as 'this country that is doubly French: French because the blood of her soldiers was shed in 1871, French because her children fought alongside the soldiers of the Great War' (L'Ikdam, March 29, 1919).

In its response to Fernand Ancey's assertion that the revolt led by Mokrani in Kabylie in 1871 was proof of Algerians' enduring hostility towards the coloniser, L'Ikdam cited an old Kabyle man who had taken part in the insurrection of 1871 and who grieved the loss of his three sons killed during the First Wold War: 'My son, all is dark around me, but this darkness does not frighten me; this darkness is shot through with a dazzling flash of lightning 
when I remember that I have redeemed myself from my mistake of 1871' (L'Ikdam, April 5, 1919). Francophile politicians who supported the Jeunes Algériens' claim for more rights echoed those views. For example, Henri Doizy, Socialist deputy for the Ardennes, drew on his childhood memories of 1870 to argue that Algerians had done their duty at the battle of Sedan and that in 1914, they had fought with the same courage as their fathers had done in Sebastopol, Italy, Tonkin, Madagascar, Tunisia and Morocco. Citing Président du Conseil (Prime Minister) Georges Clémenceau, he made reference to the insurrection of 1871 as a signal for the need for change in Algeria. He warned parliamentarians that unless reforms were introduced in the colony, further revolts could occur: 'The revolt that is brewing in Algeria will break out', he added, 'and the uprising of 1871 will be nothing compared with this future confrontation' (as quoted in L'Ikdam, March 29, 1919). As those examples have shown, memorial references to past conflicts made by the Jeunes Algériens and their allies were aimed at reconciliation and tended to reinforce calls for reform, equality and rights within the French nation, while some settlers opposed to colonial reforms used such memories of conflicts as markers of irreconcilable difference and a justification for the maintenance of settlers' dominant political position in Algeria.

\section{'What will Algeria look like in 1950?': conceptions of Algeria's future in Les Annales africaines}

The context of the year 1923 was characterised by a profound sense of disillusionment among Jeunes Algériens. The lack of significant political reform, the maintenance of the discriminatory and punitive measures of the Code de l'Indigénat imposed on Muslims, the campaigns by settlers and the Administration to undermine their action and the obstructions they faced when they engaged in the local electoral process in the colony were all 
contributory factors. While they still mentioned the sacrifice made by Algerian soldiers during the First World War in some articles, they argued that the oppressed had also learnt from the lessons of the past ( L'Ikdam, March 2, 1923). Increasingly, they criticised Western expansionism and greed and their spurious justification for waging violent wars: 'in order to fight for such vain and deplorable possessions [...], the bourgeois governments of Europe and America waged wars and sent thousands and millions of pariahs of all races to be massacred under the fallacious pretext that they were defending rights, justice and I don't know what else, as if humankind could only follow the path of progress by being drenched in mud and blood' (L'Ikdam, March 2, 1923).

Importantly, during that period, the Jeunes Algériens made more frequent connections between the past and present circumstances to conceive the possible contours of Algeria's future. They warned that in years to come 'our behaviour towards France will depend on hers towards us'. They called on the French to learn the lessons of the past and claimed that ' $[t]$ he study of the past often reveals future events' (L'Ikdam, March 23, 1923). Within this context, how was the future of Algeria and of colonial relationships envisaged by the Jeunes Algériens? How did it relate to or conflict with French conceptions of the colony's future? This section will examine instances of discourse about Algeria's destiny and assess some of the temporal references, both political and socio-cultural, that informed concerns about Algeria's future. It will assess how tensions between conceptions of the past, present circumstances and the future inflected aspects of political debate at the beginning of the 1920s and illustrate how those temporal frames conveyed differing and conflicting narratives on the colonial experience.

This discussion will focus on a case-study, a series of articles that appeared between October of 1922 and June 1923 which considered the future of the colony three decades hence. These were published in Annales africaines, the high profile Algiers weekly founded 
by prominent journalist Ernest Mallebay. In an article entitled 'French or Arab: what will Algeria be in 1950?' Mallebay argued that during the postwar period, a significant shift in colonial politics had occurred with the emergence of Muslims as a political force in Algeria. ${ }^{23}$ Stating that the forthcoming three decades would be decisive for Algeria's destiny, he invited politicians and intellectuals to write to Annales Africaines and answer the following question: 'Is France's oeuvre built on firm [inébranlable] foundations and as a consequence, will it last? Or is it doomed to be annihilated soon?' (Annales africaines, October 26, 1922). A range of contributions in the form of letters from French writers, politicians, journalists, artists, civil servants on both sides of the Mediterranean as well as from a few Algerian Muslims were published over a period of six months that provided a revealing insight into political concerns at the time. Importantly, some of the opinions on Algeria's future expressed in Annales africaines made frequent reference to the past.

One such letter was written by prominent settler Paul Cuttoli, Senator for Constantine, who argued that unless dramatic upheavals occurred in Europe, Algeria would still be under France's domination in Algeria in 1950. Revealingly, Cuttoli also drew on established references to Roman North Africa to place France's domination of Algeria within a grand narrative of historical progress and conclude nostalgically that if, due to unforeseen events, France's supremacy in Algeria were to 'perish', the legacy of French civilisation in Algeria would persist and reflect that of Rome. In his letter, the emancipation of Muslims in Algeria was likened to nature's inexorable forces of nature and described as a return to barbarism: 'North Africa will for ever be marked by French genius and will, in time, be bound up with the vivid genius of ancient Rome [...] despite the flux and reflux of Barbarism and the sands, we have faith in our ability to add our stone to the eternal monument of human destiny' (Annales africaines, December 14, 1922). 
Others invoked the Roman past to stress irreconcilable differences between the French and Algerians and express the view that Algerians were inassimilable. In his contribution to the debate, Constant-Louis Nessler, the wealthy founder of the Nessler museum and one-time Consul of Austria in Oran, also referred to North Africa's history to justify France's domination. He emphasised the importance of interrogating the past to envisage Algeria's future and argued that France could emulate the Romans by occupying North Africa for several centuries: 'History teaches us that $[\ldots]$ the Romans never really managed to assimilate native populations [...] but this did not prevent them from maintaining their sovereignty on this land for more than five centuries'. Nessler argued that the French were the true heir of the Romans and rejected the notion that Arabs could legitimately claim Algeria as an independent nation: 'The Arabs are not really at home in Algeria because they did not occupy this country; they merely resided there if one understands the real meaning of the term 'occupation' which implies a long succession of works to develop this land. Now what prolific traces has they left over the last fourteen centuries? Where are their roads, their ports, their bridges, their dams?' (Annales africaines, February 15, 1923).

By contrast to the range of contributions by French writers and politicians - many of which referred to the past - only a small number of letters written by Algerian Muslims, notably one by Emir Khaled, were published in Annales africaines as part of this debate on Algeria's future. In his letter, Khaled looked back on France's colonial rule in Algeria to paint a bleak picture of colonial Algeria. He criticised Mallebay's argument about Muslims being largely equal to the French and, implicitly, drew a pessimistic portrait of Algeria's future under France's rule:

Rather, you should say that they are your servants, that they fulfil all the duties of French citizens including through the blood tax, and that their only right is to remain silent, live as inferior beings, be ruled by special legislation, be judged by special courts and be subjected to 
administrative surveillance [...] If you wish to have a more direct answer to your question [...] you should examine what the Administration has done for natives for the last 92 years and your very conscience will provide you with the answer that you are looking for (Annales africaines, December 14, 1922).

In his detailed response to Mallebay's question, Khaled focused specifically on the inequity of the colonial situation in Algeria rather than on broader historical claims to reinforce his political argument. He condemned the efforts made by the Algerian administration to 'sabotage' the law of 4 February 1919 and the prorogation of the punitive measures of the Native Code affecting Muslims. His letter to Annales africaines painted a portrait of a North African land stultified by colonisation and an Algerian people suffering in poverty. The Algerian population, he claimed, 'has barely evolved on an educational level since 1830', adding that: 'however, one should note that people were not as poor and destitute then as they are today. They are doomed to remain subjects under French rule' (Annales africaines, December 14, 1922). It is worth noting however that in L'Ikdam, Emir Khaled invoked the past to suggest that colonial rule in Algeria would come to an end unless significant reforms were not introduced: 'Hasn't tradition taught us this truth: "The reign of a just people will last [...] that of the unjust is bound to disappear"' (L'Ikdam, March 16, 1923).

\section{Conclusion}

In his study of the political currency of the past, Martin Heisler highlights the pervasiveness of the past in people's lived experience, as well as its relationship with the process of identity formation (Heisler 2008a, 16-17). History, memory and identity, he argues, are 'interdependent variables shaped by such political acts as elite-constructed stories of the past and collective memories or as socially or politically shaped objects, such as memorials and 
symbols'. Politics, he adds, is 'the main independent variable or creative force that moulds history, memory and identity' (Heisler 2008b, 201). In the context of colonial Algeria, negotiating the past was an inherently fraught political process that reflected and shaped identities. For much of the nineteenth century, the hegemonic position enjoyed by the coloniser in Algeria ensured that history and memory were invoked by colonists in ways that either sustained, explained or justified France's imperial project. Such discourse, it could be argued, was also about 'colonising' the past. Particular interpretations of the past were used by some French liberal intellectuals and politicians as tools to argue their case against the injustices generated by France's imperial ambitions.

However, by the early twentieth century and particularly in the aftermath of the First World War, the political context had evolved in significant ways. Increasingly, in this period marked by social, cultural and political tensions and by the concatenation of events triggered by the War, colonial identities became informed by shifting and often competing conceptions of the past. The modest reforms introduced by the Jonnart Law of 4 February 1919 failed to alter in any meaningful way the discrimination and marginalisation that Algerians experienced under colonial rule. Importantly, the emergence of the Jeunes Algériens as a small but influential political movement that demanded colonial reforms, a gradual shift towards equality and fairer political representation for Algerians inflected political debates in a number of ways. As Ernest Mallebay stated in 1922: 'In the past, for us, the native question used to be limited to our policy towards our Muslim subjects. Today, this question is broader as it also includes Muslims' policy towards us' (Annales africaines, October 26, 1922).

During that period, a number of French narratives continued to rely on notions of history that reinforced the view that there existed irreconcilable differences between the coloniser and the colonised. On the one hand they invoked North Africa's Roman past as an inspiration and justification for continued French colonial rule and 'civilising influence' in 
Algeria and on the other, negated and expunged traces of vernacular cultures and the Muslim past of North Africa. It was, to a large extent, a closed conception of the temporality that reinforced colonial divisions, maintained the colonial status quo and confined the colonised to the role of a subject for whom assimilation was an elusive 'smokescreen', to use Emir Khaled's term. Memories of the colonial period were invoked by settlers and the Administration as a way of celebrating France's 'œeuvre de régénération' (work of regeneration) and sustain the myth of the settler pioneer in Algeria. By contrast, past resistance to colonisation by Algerians constituted, in their view, a reminder of Muslims' hostility towards the civilising process and against French rule, and an indication that granting political rights to Algerians could spell the end of French domination in Algeria. Conceptions of the past also informed some of the problematic views on Algeria's future expressed by some of the French writers, politicians, civil servants and settlers who took part in the debate on Algeria's future in Annales africaines in 1922 and 1923.

For the Jeunes Algériens too, the past constituted an important resource for the articulation of their political project. It formed part of a counter-discourse that aimed to challenge colonial narratives on Algeria's past that marginalised the colonised, reinforce the legitimacy of their action and humanise the experience of Algerians. The historical framework that they used echoed, to some extent, that of the colonists. But they also sought to disrupt French discourse by reclaiming aspects of their past negated by the colonists, construct or imagine an empowering historical narrative that chimed with their political concerns at the time, and suggest an open conception of temporality fostering change and reform of the colonial order.

Narratives that linked the past to the present focused essentially on notions of high culture. To France's historical imagination of a direct connection between the Roman past in North Africa and France's colonial project in Algeria, the Jeunes Algériens opposed with a 
discourse celebrating the achievements of the past greatness of Arab civilisation, the role Muslims forebears played in safeguarding and enhancing the ancient Greeks' cultural and scientific heritage and their influence on European culture. Importantly, the diversity of North Africa's vernacular, popular cultural identities was effaced or denigrated on both sides of the colonial divide. The memorial references foregrounded by the Jeunes Algériens such as the sacrifice made by Muslim soldiers during French military campaigns also sought to reinforce their claims for rights and acceptance within the French nation. Interestingly, the few contributions by Algerian Muslims to the debate on Algeria's future published in Annales africaines did not draw on history as an inspiration. They focused, instead, on the 'here and now' of the experience of the colonised to suggest that Algeria's future would be determined by France's ability to change course and introduce profound reform in the colony. What those French and Algerian discourses conveyed were two mirroring, yet conflicting conceptions of belonging, temporality and the colonial experience that not only affected relationships at the time but also shaped political debate in the following decades. 


\section{Notes}

${ }^{1}$ Pierre Nora argues that ' $[\mathrm{m}]$ emory and history, far from being synonymous, appear now to be in fundamental opposition' (Nora 1989, 8).

${ }^{2}$ See, for example, Anderson 2011, Traverso 2005, and Traverso 2012.

${ }^{3}$ Here, Traverso draws on the work of Myers (2002).

${ }^{4} \mathrm{~A}$ brief outline of the Jeune Algérien movement is provided in this article. For a detailed study of the historical development of the Jeunes Algériens, see, for example, Ageron (2005), Kaddache (1973), Koulakssis and Meynier (1987).

${ }^{5}$ Here, Brow draws on the work of Michel Foucault and Antonio Gramsci.

${ }^{6}$ M'hamed Ben Rahal was the first Algerian Muslim to get the French baccalaureate.

${ }^{7}$ Algerian Muslims were classed as French subjects and not as citizens. Prior to the modest reforms introduced by the Law of 4 February 1919, they could not vote nor could they be elected. They did not have access to most civil service jobs, and Muslim law applied to them in terms of their personal status and private law. Unlike Algerian Jews who were assimilated and granted French citizenship by the Crémieux decree of 24 October 1870, the sénatus-consulte of 14 July 1865 and the decree of 21 April 1866 required Algerians to apply for French citizenship individually and to formally renounce their personal status as Muslims, which very few were willing to do. For example, only 37 Algerians gained French citizenship in 1907, and just 19 in 1909 (De Boeck 1912).

${ }^{8}$ In May 1919, Emir Khaled led a Jeune Algérien delegation that submitted a petition addressed to President Wilson in Paris. In this document, they denounced France's oppressive colonial rule in Algeria and called for Algerians to have delegates chosen by Algerians to determine Algeria's future under the aegis of the League of Nations (Ageron 1980, 203). On the influence that Woodrow Wilson's discourse on peoples' right to selfdetermination had on political movements in the colonies, see Manela (2007).

${ }^{9}$ The decrees of 1912 that introduced the partial conscription of Algerians were staunchly opposed by settlers, by colonial administrators and by many Muslim notables close to the administration in Algeria. In September 1916, conscription was imposed on all Algerian men ('Le Sous-Préfet de l'arrondissement d'Orléansville à Monsieur le Préfet d'Alger', 12 September 1908 ; 'Le Sous-Préfet de Tizi-Ouzou à Monsieur le Préfet d'Alger', 14 September 1908). See also Meynier (2015, 89-113).

${ }^{10}$ On Victor Barrucand, see Drouot and Vergnot (1984, 31-36).

${ }^{11}$ Calls for more schools to be built for Muslims continued to be made by Jeunes Algériens in the post-war period.

${ }^{12}$ The first issue of $L$ 'Ikdam was published on 7 March 1919. This weekly newspaper was created following the merger of L'Islam and Le Rachidi - edited by Sadek Denden and Hamou Hadj Ammar respectively.

${ }^{13}$ The readership of this newspaper grew steadily as it was actively promoted in Algerian's urban centres. It was estimated by the Affaires indigènes that by the autumn of 1919, more than 200 Algerians subscribed to this newspaper in Mascara alone, and many more in Tlemcen ('Rapport mensuel sur la situation politique et administrative des indigènes durant le mois de septembre 1919'. 1919).

${ }^{14}$ According to the census of 1911, there were 4.7 million Muslim French subjects' in Algeria (Kateb 2001, 120).

${ }^{15}$ The Comité d'Action Franco-Musulman was founded in 1915 following the death of several prominent supporters of colonial reform in Algeria (Albin Rozet, député of the Haute [1852-1915]; Paul Bourdes, journalist for Le Temps [1851-1914] and Senator Louis Pauliat [1845-1915]). The aim of the Comité whose President was Edouard Herriot, député and mayor of Lyon, was to 'defend the interest of the Muslim population before the French authorities and fight for their moral, intellectual, economic, administrative and political situation' (L'Ikdam, 15 March 1919). Its members played an important role in the adoption of the law of 4 February 1919 that granting some more political rights to Algerian Muslims.

${ }^{16}$ On Louis Bertrand and Robert Randau, see for example, Dunwoodie (1998); Dunwoodie (2010); and Haddour (2000).

${ }^{17}$ Fernand Ancey wrote: 'French civilisation should leave a more durable mark on our French Africa than previous civilised peoples, primarily the Romans' (L'Echo d'Alger, March 2, 1919).

${ }^{18}$ For example, at the Congress of Mayors of Kabylie of 23 February 1920, settler representatives warned that the Law of 4 February 1919 granting some rights to Algerians was 'premature and represented a danger to public safety'. It was contributing to a 'resurgence of Muslim fanaticism and nationalism' in Algeria (La Voix des Colons, February 29, 1920, Dépêche algérienne, March 15, 1920).

${ }^{19} \mathrm{See}$, for example, Gouvernement général de l'Algérie, Conseil supérieur de gouvernement $(1938,24)$.

${ }^{20}$ On the Kabyle uprising of 1871 , see, for example, Salhi (2012, 103-109). On the revolt of Margueritte in 1901, see Phéline (2012). 
${ }^{21}$ Adolphe Messimy (1869-1935) was an army general and politician who instigated the introduction of conscription for Algerian subjects. He briefly served as Minister for Colonies and as War Minister before the War.

${ }^{22}$ Mohamed Soualah was an Arabic teacher, Omar Bouderba, a trader based in Algiers, Ben Ali Mouhoub, a tobacco manufacturer and Mustapha Tamzali, a businessman.

${ }^{23}$ Here, Mallebay echoed the views already expressed by columnist Jules Rouanet in the pro-colonial newspaper La Dépêche algérienne.

\section{References}

Ageron, Ch.-R. 1980. "La pétition de l'Emir Khaled au Président Wilson (mai 1919)", Revue d'Histoire Maghrébine 7, no. 19-20, 199-209.

Ageron, Ch.-R. 2005. Les Algériens musulmans et la France (1871-1919). St Denis: Editions Bouchène.

Annales africaines, October 26, 1922.

Annales africaines, December 14, 1922.

Annales africaines, February 15, 1923.

Anderson, P., 2011. The New Old World. London: Verso.

Bernard, P. 1912. "Un homme et une œuvre", Bulletin de la Société amicale des membres de l'enseignement des indigènes de l'Algérie, no. 21, $2^{\text {ème }}$ trimestre, p. 5.

Boissier, G. 1912. L'Afrique romaine. Promenades archéologiques en Algérie et en Tunisie (5th ed.). Paris: Hachette.

Brow, J. 1990. "Notes on Community, Hegemony, and the Uses of the Past". Anthropological Quarterly 63 (1): 1-6.

“Comment organiser l'Afrique du Nord! Articles du Temps et de la Revue Indigène". 1912. Bibliothèque de la Revue Indigène.

De Boeck, C. 1912. "La naturalisation des indigènes musulmans et l'accession aux droits politiques dans l'Afrique du Nord". Revue de Droit international privé et de droit pénal international 8: 195-196.

Dépêche algérienne, March 15, 1920. 
Dosse, F. 1998. "Entre histoire et mémoire : une histoire sociale de la mémoire". Raison présente, no. 128: 5-24.

Dosse, F. 2003. "Michel de Certeau et l'écriture de l'histoire". Vingtième siècle, revue d'histoire, no. 78: 145-156.

Drouot, C., and Vergnot, O. 1984. "Victor Barrucand, un indésirable à Alger". Revue de l'Occident musulman et de la Méditerranée, no. 37: 31-36.

Dunwoodie, P. 1998, Writing French Algeria, Oxford: Clarendon Press.

Dunwoodie, P. 2010. "Colonizing Space: Louis Bertrand's Algeria in Le sang des races and Sur les routes du sud”, Modern Language Review 105 (4): 997-1014.

L'Echo d'Alger, March 2, 1919.

L'Echo d'Alger, February 16, 1919.

L'Echo d'Alger, March 16, 1919.

El Hack, January 14, 1894.

Halbwachs, M. 1968. La Mémoire collective. Paris : Presses universitaires de France.

Fabre, C.-A. 1901. Grande-Kabylie: légendes et souvenirs. Paris: Léon Vanier.

Fromage, Julien. 2012. “L'expérience des « Jeunes Algériens » et l'émergence du militantisme en Algérie (1880-1919)". In Histoire de l'Algérie à la période coloniale (18301962), edited by Abderrahmane Bouchène, Jean-Pierre Peyroulou, Ouanassa Siari Tengour, and Sylvie Thénault, 239-43. Paris: La Découverte.

Gilpin, R. 1981, War and Change in World Politics, Cambridge: Cambridge University Press.

Gouvernement général de l'Algérie, Délégations financières. 1918. Session du 22 juin 1918. No. 2, Algiers: Imprimerie Administrative Victor Heintz.

Gouvernement général de l'Algérie, Délégations financières algériennes. 1926, "Session ordinaire de 1926, No. 2, Délégation des colons (séance du 26 mai 1926)", Algiers: Imprimerie administrative Victor Heintz.

Gouvernement général de l'Algérie, 1938, 'Allocution de M. le professeur Lebon [Viceprésident du Conseil supérieur de l’Algérie]', 1938, Conseil supérieur de gouvernement, session ordinaire de 1938, Alger: Victor Heintz.

Haddour, A. 2000. Colonial Myths: History and Narrative, Manchester: Manchester University Press. 
Heisler, M. O. 2008a. 'Introduction: the Political Currency of the Past: History, memory, and Identity'. The Annals of the American Academy of Political and Social Science 617: 14-24.

Heisler, M. O. 2008b. 'Challenged Histories and Collective Self-Concepts: Politics in History, memory and Time'. The Annals of the American Academy of Political and Social Science 617: 199-211.

Hutton, P. H. 1993. History as an Art of Memory. Hanover, N. H.: University of Press of New England.

L'Ikdam, March 7, 1919.

L'Ikdam, March 15, 1919.

L'Ikdam, March 22, 1919.

L'Ikdam, March 24, 1919.

L'Ikdam, March 29, 1919

L'Ikdam, April 5, 1919.

L'Ikdam, November 17, 1919.

L'Ikdam, February 2, 1923.

L'Ikdam, March 2, 1923.

L'Ikdam, March 16, 1923.

L'Ikdam, March 23, 1923.

L'Islam, January 7, 1912.

L'Islam, February 11, 1912.

L'Islam, February 25, 1912.

L'Islam, March 5, 1914.

Kaddache, M. 1973. 'L'Emir Khaled, jeune étudiant et officier'. Revue de l'Histoire et de la Civilisation du Maghreb, no. 10: 101-107.

Kateb, K. 2001. Européens, 'indigènes' et juifs en Algérie (1830-1962), Représentations et réalités des populations. Paris: Éditions de l'Institut national démographique.

Koulakssis, A., and Meynier, G. 1987, L'Emir Khaled, premier za'îm? Paris: L'Harmattan. 
Liu, J. H., and Hilton, D. 2005. 'How the past weighs on the present: Social representations of history and their role in identity politics'. British Journal of Social Psychology, no. 44: 537-556.

'Le Sous-Préfet de l'Arrondissement d'Orléansville à Monsieur le Préfet d'Alger', 12 September 1908. ANOM 9H4 (Archives Nationales d'Outre-Mer, Aix-en-Provence, France).

'Le Sous-Préfet de 1'Arrondissement de Tizi-Ouzou à Monsieur le Préfet d'Alger', 14 September 1908. ANOM 9H4.

Lomont, A. 1924. La Route de la victoire. Histoire de la Grande Guerre, août 1914novembre 1918. Paris: Librairie Gedalge.

Lorcin, P. M. E. 2002. 'Rome and France in Africa: Recovering Colonial Algeria's Latin Past'. French Historical Studies 25 (2): 295-329.

Manela, Erez. 2007. The Wilsonian Moment: Self-Determination and the International Origins of Anticolonial Nationalism. Oxford: Oxford University Press.

May, J., and Thrift, N. 2003. 'Introduction'. In Timespace: Geographies of Temporality, edited by John May, and Nigel Thrift, 1-46. London: Routledge.

Meynier, G. 2015. L'Algérie révélée: La guerre de 1914-18 et le premier quart du XXe siècle. Saint-Denis: Éditions Bouchène.

Mourey, C., and Brunel, L., eds. 1902 (December). L'année coloniale; troisième année (1901). Paris: Société de l'annuaire colonial.

Myers, D. N. 2002. 'Selbstreflexion im modernen Erinnerungsdiskurs'. In Jüdische Geschichtsschreibung heute: Themen, Positionen, Kontroversen, edited by Michael Brenner, and David Meyers. Munich: Beck Verlag.

Nora, P. 1989. 'Between Memory and History: Les Lieux de Mémoire'. Representations. no. 26: $7-24$

Phéline, C. 2012. L'aube d'une révolution. Margueritte, Algérie, 26 avril 1901. Toulouse: Éditions Privat.

'Rapport mensuel sur la situation politique et administrative des indigènes durant le mois de septembre 1919'. ANOM 11H46.

'Rapport sur la situation politique et administrative des indigènes de l'Algérie au $1^{\mathrm{er}}$ mai 1923', ANOM 11H46.

Salhi, M. B. 2012. 'L'insurrection de 1871'. In Histoire de l'Algérie à la période coloniale (1830-1962), edited by Abderrahmane Bouchène, Jean-Pierre Peyroulou, Ouanassa Siari Tengour, and Sylvie Thénault, 103-109. Paris: La Découverte. 
Stora, B. 1996. Ils venaient d'Algérie. L'immigration algérienne en France, 1912-1992. Paris: Fayard.

Traverso, E. 2005. Le passé: mode d'emploi. Paris: La fabrique.

Traverso, E. 2012. L'histoire comme champ de bataille: interpréter les violences du XXe siècle. Paris: La Découverte.

La Voix des Colons, February 29, 1920.

Vachon, M. 1916. La Guerre artistique avec l'Allemagne. L'organisation de la victoire. Paris: Payot. 